\title{
Pengaruh Penambahan Biotin Pada Media Pertumbuhan Terhadap Produksi Sel Aspergillus niger
}

\author{
Wuryanti \\ Jurusan Kimia FMIPA UNDIP
}

\begin{abstract}
Aspergillus niger is one of microorganisms which has potensial as L-asparaginase source. Biotin are vitamins soluble in water and have function to facilitate the increasing cell growth. The research has purposes to determine the influences of adding biotin into growing medium of Aspergillus niger to its cell production. The results from research show that the optimum incubation time for producing biomass weight of Aspergillus niger was at the $48^{\text {th }}$ hour. Addition of biotin $0.1 \mathrm{mg} / \mathrm{L}$ into growing medium of Aspergillus niger might increase biomass weight of Aspergillus niger until $40.17 \%$.
\end{abstract}

Key word : Aspergillus niger, Biotin, Biomasa.

\section{PENDAHULUAN}

Biotin merupakan vitamin yang larut dalam air, biasa disebut vitamin $\mathrm{H}$, yang termasuk dalam vitamin B komplek. Dalam penelitian ini biotin yang digunakan berfungsi untuk membantu meningkatkan pertumbuhan sel, sehingga dapat diperoleh asparaginase yang maksimal (Bonjour, 1991).

Aspergillus niger dikenal sebagai salah satu mikroorganisme yang memiliki kemampuan tinggi untuk menghasilkan enzim asparaginase. Biotin berperan dalam membantu pertumbuhan sel mikroorganisme. Pengamatan terhadap pengaruh penambahan biotin pada media pertumbuhan Aspergillus niger terhadap produksi perlu dilakukan sebagai langkah awal sebelum proses industri.

Untuk mengetahui pengaruh penambahan biotin pada media pertumbuhan Aspergillus niger terhadap produksi.sel maka perlu dilakukan penentuan kurva pertumbuhan kemudian dilanjutkan produksi sel tersebut.

\section{1.,Aspergillus niger}

Kedudukan Aspergillus niger adalah sebagai berikut :

$\begin{array}{ll}\text { Kingdom } & \text { : Fungi } \\ \text { Filum } & \text { : Ascomycota } \\ \text { Klas } & \text { : Ascomycetes } \\ \text { Ordo } & \text { : Eurotiales } \\ \text { Famili } & : \text { Trichocomaceae } \\ \text { Genus } & : \text { Aspergillus } \\ \text { Spesies } & \text { : Aspergillus niger }\end{array}$

(Samson, et al.,1996)
Ciri-ciri Aspergillus niger yaitu mempunyai kepala konidia yang besar, bulat dan berwarna hitam, coklat hitam atau ungu coklat. Konidianya kasar dan mengandung pigmen, hifa septat dan miselium bercabang. Konidiofora membengkak membentuk vesikel pada ujungnya membawa sterigmata dimana tumbuh konidia. Konidia membentuk rantai berwarna hijau, coklat atau hitam, Jamur ini tumbuh baik pada suhu kamar dan pada medium $\mathrm{pH}$ asam.

Aspergillus niger merupakan kapang yang dapat digunakan untuk menghasilkan berbagai jenis asam seperti asam oksalat, asam-2hidroksipropana-1,2,3-trikarboksilat, asam glukonat dan beberapa jenis enzim seperti pektinase, $\alpha$-amylase, asparaginase, selulase, proteinase, lipase, katalase, glukosa oksidase dan fitase.

Aspergillus niger dapat tumbuh cepat
dengan menggunakan nutrisi yang ada disekelilingnya. Molekul-molekul sederhana seperti monosakarida yang terlarut disekeliling hifa dapat diserap langsung oleh hifa, tetapi polimer-polimer seperti amilum atau selulosa harus dipecah dulu oleh enzim-enzim ekstraseluler yang dihasilkan oleh Aspergillus niger menjadi molekul-molekul yang lebih sederhana sebelum diserap ke dalam sel (Fardiaz, 1992).

\section{KURVA PERTUMBUHAN MIKROBA}

Pertumbuhan mikroba dalam suatu kultur melewati beberapa fase yaitu: 


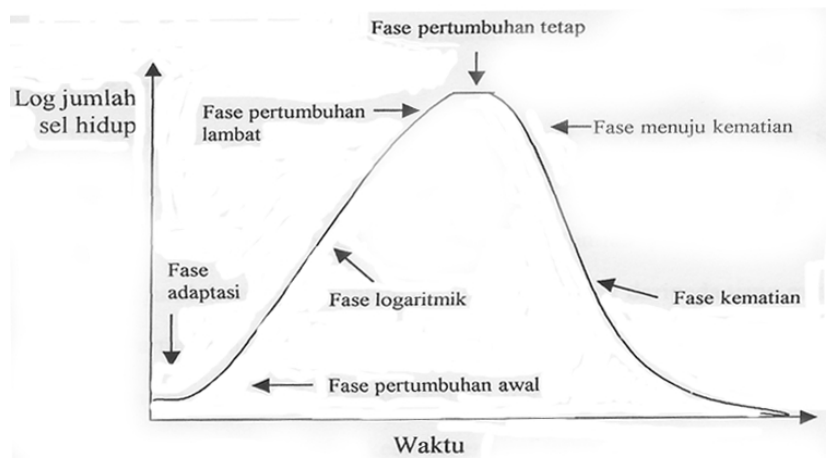

Gambar 1: Kurva pertumbuhan mikroba

\section{a. Fase Adaptasi}

Fase adaptasi adalah fase penyesuaian mikroba dengan kondisi lingkungan baru di sekelilingnya. Jumlah awal sel yang dipindah ke media baru mempengaruhi cepat lambatnya fase adaptasi. Bila media dan lingkungan pertumbuhan sama dengan media sebelumnya, mungkin tidak diperlukan waktu adaptasi.

b. Fase Pertumbuhan Awal

Mikroba mulai membelah diri dengan kecepatan yang rendah karena baru menyesuaikan diri.

c. Fase Pertumbuhan Logaritmik

Mikroba membelah dengan cepat dan konstan mengikuti kurva logaritmik. Kecepatan pertumbuhan sangat dipengaruhi oleh $\mathrm{pH}$, kandungan nutrien, suhu dan kelembaban udara. Pada fase ini kultur paling sensitif terhadap keadaan lingkungan.

d. Fase Pertumbuhan Lambat

Pertumbuhan populasi mikroba diperlambat karena zat nutrisi sudah sangat berkurang dan ada hasil metabolisme yang mungkin beracun atau dapat menghambat pertumbuhan mikroba. Jumlah populasi masih naik karena jumlah sel yang tumbuh masih lebih banyak daripada yang mati.

e. Fase Pertumbuhan Tetap

Jumlah sel yang tumbuh sama dengan jumlah sel yang mati. Ukuran sel pada fase ini menjadi lebih kecil karena sel tetap membelah meskipun zat-zat nutrisi sudah habis. Karena kekurangan nutrisi, sel mempunyai komposisi berbeda dengan sel yang tumbuh pada fase logaritmik. f. Fase Menuju Kematian dan Fase Kematian

Sebagian besar populasi mikroba mulai mengalami kematian karena nutrien di dalam medium sudah habis, adanya zat racun dan habisnya energi cadangan di dalam sel. Kecepatan kematian tergantung dari kondisi nutrien, lingkungan dan jenis mikroba (Suhartono, 1989).

\section{BIOTIN}

Biotin merupakan vitamin yang larut dalam air, biasa disebut vitamin $\mathrm{H}$, yang termasuk dalam vitamin B komplek. Struktur Kimia biotin adalah sebagai berikut<smiles>O=C(O)CCC1CSC2NC(=O)NC12</smiles>

\section{Gambar 2. Struktur Kimia Biotin}

Biotin sebagai kofaktor terikat kuat pada bagian protein enzim. Ada tiga jenis reaksi yang dapat dilangsungkan oleh biotin yaitu :

a) Reaksi Karboksilasi pada karbon dari asil Ko A

b) Reaksi Karboksilasi pada atom karbon yang berikatan ganda dari rantai karbon senyawa asil Ko A

c) Reaksi transkarboksilasi pada senyawa asil Ko A (Poedjiadji, 1994).

Biotin banyak terdapat dalam jaringan hewan dan tumbuh-tumbuhan, dan kemungkinan merupakan senyawa yang umum terdapat dalam sel-sel makhluk hidup. Biotin alami terdapat dalam bentuk bebas seperti pada sayuran, buah-buahan, susu dan bekatul, juga dalam bentuk terikat dengan protein seperti yang terdapat dalam jaringan, benih tanaman dan khamir. Sumber biotin yang kaya atau penting bagi manusia adalah ginjal, hati, daging, khamir, kuning telur, susu, keju, jamur, beberapa sayuran dan lembaga atau bekatul bijibijian. 
D-biotin merupakan kristal bubuk berwarna putih atau kristal berbentuk jarum tidak berwarna. Vitamin ini sedikit larut dalam air dan larut dalam alkohol, alkali encer dan air panas, agak larut dalam asam encer dan sama sekali tidak larut dalam pelarut-pelarut organik seperti kloroform, eter dan petroleum eter. Bentuk kristal kering d-biotin stabil terhadap udara, cahaya dan panas tetapi secara perlahan-lahan dapat dirusak oleh radiasi sinar ultraviolet.

Larutan d-biotin stabil terhadap kondisi asam dan basa lemah. Tetapi

dalam kondisi asam atau basa kuat aktivitas biologis biotin akan rusak jika dipanaskan. Sebaliknya larutan netral stabil terhadap pemanasan $100^{\circ} \mathrm{C}$.

Kristal d-biotin mempunyai titik lebur 229-232 ${ }^{0} \mathrm{C}$ dan berat molekulnya adalah

224,31. Jika dilarutkan dalam $0,1 \mathrm{~N} \mathrm{NaOH}$, biotin mempunyai aktivitas optik $[\alpha] 25_{\mathrm{D}}=+92^{0}$. Sedang jika dilarutkan larutan $\mathrm{MeOH}$, biotin dapat menyerap spektrum ultraviolet dengan panjang gelombang maksimum $235 \mathrm{~nm}$ (Andarwulan dan Sutrisno, 1992).

Aspergillus niger merupakan salah satu mikroorganisme yang memiliki potensi sebagai sumber enzim asparaginase. Penelitian ini diawali dengan penanaman jamur Aspergillus niger dalam medium agar miring (Taoge Ekstrak Agar/TEA) terlebih dahulu. Kemudian Aspergillus niger dipindahkan pada medium pertumbuhan (Czapek cair) dengan penambahan biotin yang divariasi konsentrasinya. Selanjutnya biomassa ditentukan, untuk mengetahui pengaruh penambahan biotin terhadap produktivitas sel. Penelitian ini dilakukan di Laboratorium Biokimia F. MIPA UNDIP.

\section{BAHAN DAN METODE}

\section{Alat}

Alat-alat yang digunakan dalam penelitian ini adalah: sentrifuge

centrific-228, magnetik stirer guart, selofan, inkubator Memmert, botol semprot, timbangan elektrik, jarum osse, pH meter Oroin $420 \mathrm{~A}$, alatalat gelas untuk analisis.

2. Bahan

Bahan-bahan yang diperlukan dalam penelitian ini adalah : Aspergillus niger
6088 IFO 6341, biotin p.a, TEA (Taoge Ekstrak Agar), alkohol 60\%, glukosa, amonium nitrat, kalium hidrogen fosfat, magnesium sulfat heptahidrat, aquades, kapas.

3. Cara Kerja

1. Pembuatan medium agar miring TEA (Taoge Ekstrak Agar)

Sebanyak 100 gram taoge direbus dengan $1 \mathrm{~L}$ akuades selama 2 jam, lalu disaring. Kemudian ditambahkan 60 gram gula pasir dan direbus sampai gula larut. Akuades ditambahkan sampai dengan volume semula (1L), sebanyak 20 gram agar-agar dimasukkan dan diaduk sampai larut selama 20 menit. Sebanyak $5 \mathrm{~mL}$ larutan TEA dituang kedalam tabung reaksi, tabung ditutup dengan kapas dan kertas sampul, kemudian diikat dengan benang. Medium disterilkan dalam autoklaf selama 15 menit pada suhu $121^{\circ} \mathrm{C}$, kemudian didiamkan dalam posisi miring selama 24 jam pada suhu kamar. Medium siap digunakan (Gandjar, et al.,1999).

2. Pembuatan media pertumbuhan jamur (Czapek cair)

Sebanyak 50 gram glukosa, 2,06 gram amonium nitrat, 1,2 gram kalium hidrogen fosfat dan 0,5 gram magnesium sulfat heptahidrat diencerkan dengan akuades hingga volume larutan menjadi $1 \mathrm{~L}, \mathrm{pH}$ diatur sampai 3,5. Larutan dituang sebanyak $30 \mathrm{~mL}$ kedalam botol $150 \mathrm{~mL}$, botol ditutup dengan kapas dan kertas sampul, kemudian diikat dengan benang. Larutan disterilkan dalam autoklaf pada suhu $121^{\circ} \mathrm{C}$ selama 15 menit. Medium didinginkan dan didiamkan selama 24 jam pada suhu kamar. Medium siap digunakan (Poesponegoro dan Liang, 1991).

3. Penanaman jamur Aspergillus niger pada medium agar miring (TEA)

Jarum osse dicelupkan dalam alkohol $60 \%$ lalu dipijarkan pada nyala api spiritus. Tabung yang berisi biakan Aspergillus niger murni dan tabung berisi medium TEA dibuka, kemudian dipanaskan ujung kedua tabung pada nyala api spiritus. Dengan menggunakan ujung jarum osse diambil biakan murni kemudian ditanamkan kedalam medium TEA dengan cara menggores dari pangkal ke ujung tabung secara zig-zag. Kedua tabung disterilkan kembali dengan cara bagian mulut tabung reaksi dipanaskan pada nyala api spritus kemudian kedua tabung tersebut ditutup 
kembali. Biakan dalam medium TEA diinkubasi pada suhu kamar selama 3 hari (Hadioetomo dan Ratna, 1987).

4. Penanamam jamur Aspergillus niger dalam medium pertumbuhan (Czapek cair)

Jarum osse disterilkan dengan cara seperti diatas. Penutup tabung yang berisi biakan dalam medium TEA dan penutup tabung yang berisi air steril dibuka kemudian bagian mulut kedua tabung tersebut dipanaskan dalam nyala api spritus. Dengan menggunakan ujung jarum osse biakan diambil dan disinggungkan pada air steril. Tabung yang berisikan air dikocok hingga biakan rata dalam air tersebut. Tutup botol medium pertumbuhan (Czapek cair) dibuka dan disterilkan dengan memanaskan mulut botol dalam nyala api spiritus. Sebanyak $0,5 \mathrm{~mL}$ jamur Aspergillus niger dipindahkan ke dalam medium pertumbuhan (Czapek cair) dengan menggunakan pipet steril. Kemudian botol disterilkan kembali dalam nyala api spiritus dan ditutup kembali. Biakan diinkubasi dengan shaker goyangan $200 \mathrm{rpm}$ pada suhu kamar selama $48 \mathrm{jam}$. Ulangi percobaan diatas dengan penambahan biotin dalam berbagai konsentrasi $(0 ; 0,025 ; 0,05 ; 0,075 ; 0,1 \mathrm{mg} / \mathrm{L})$ (Hadioetomo dan Ratna,1987).

5. Penentuan biomassa

Larutan disentrifugasi $3400 \mathrm{rpm}$ selama 15 menit kemudian disaring untuk memisahkan jamur. Jamur yang diperoleh dicuci dengan akuades, dikeringkan pada suhu $80^{\circ} \mathrm{C}$ selama 24 jam kemudian ditimbang (Suharto, 1995).

\section{HASIL DAN PEMBAHASAN}

1. Peremajaan dan Pembiakan Jamur Aspergillus niger

Jamur Aspergillus niger merupakan salah satu sumber potensial enzim asparaginase. Penelitian ini mencoba untuk mengamati pengaruh penambahan biotin pada media pertumbuhan jamur Aspergillus niger terhadap produksi sel. Tahap awal adalah peremajaan dan dilanjutkan pembiakan jamur Aspergillus niger. Jamur Aspergillus niger diremajakan pada media agar miring TEA (Taoge Ekstrak Agar) steril. Tujuan tahap peramajaan Aspergillus niger adalah memperoleh spora yang masih muda untuk menghasilkan produk yang lebih baik, sehingga pada tahap ini diharapkan memperoleh jamur
Aspergillus niger yang aktif. Peremajaan jamur Aspergillus niger dilakukan dengan memindahkan sejumlah kecil biakan murninya ke medium TEA yang berbentuk agar miring. Medium ini digunakan sebab medium TEA mengandung senyawa-senyawa yang diperlukan untuk pertumbuhannya. Senyawa-senyawa tersebut adalah glukosa sebagai sumber karbon dan sumber energi, juga ekstrak kecambah sebagai sumber nitrogen, karbon serta unsur-unsur kelumit seperti garam-garam mineral. Kemudian jamur Aspergillus niger hasil peremajaan dipindahkan pada media pertumbuhannya (Czapek cair) yang telah disterilisasi terlebih dahulu. Sterilisasi media dilakukan dengan menggunakan autoklaf klinis tekanan $2 \mathrm{~atm}$ pada suhu $121{ }^{\circ} \mathrm{C}$ selama 15 menit. Suhu dan tekanan tinggi akan memperbesar penetrasi uap air ke dalam sel-sel mikrobia yang menyebabkan koagulasi protein-protein protoplasma dan mempercepat kematian mikrobia, sehingga diharapkan didapatkan media yang steril, bebas dari mikroorganisme lain.

\section{Penentuan Kurva Pertumbuhan.}

Setelah peremajaan dilakukan penentuan kurva pertumbuhan, Hal ini untuk mengetahui kapan jamur tersebut harus dipanen atau kapan jamur tersebut menghasilkan sel paling banyak.Berikut data dari penentuan kurva pertumbuhan;

\section{DATA KURVA PERTUMBUHAN}

\section{ASPERGILLUS NIGER}

\begin{tabular}{ccc}
\hline $\begin{array}{c}\text { Waktu } \\
\text { jam) }\end{array}$ & \multicolumn{2}{c}{$\begin{array}{c}\text { berat basah Aspergillus niger } \\
\text { (gram) }\end{array}$} \\
\cline { 2 - 3 } & Tanpa biotin & Dengan biotin \\
\hline $\mathbf{1 0}$ & 0,0762 & 0,0805 \\
$\mathbf{2 0}$ & 0,1012 & 0,1220 \\
$\mathbf{3 0}$ & 0,1361 & 0,1478 \\
$\mathbf{4 0}$ & 0,1600 & 0,1638 \\
$\mathbf{4 2}$ & 0,1865 & 0,1914 \\
$\mathbf{4 4}$ & 0,2197 & 0,2234 \\
$\mathbf{4 6}$ & 0,2531 & 0,2745 \\
$\mathbf{4 8}$ & 0,2928 & 0,3124 \\
$\mathbf{5 0}$ & 0,2610 & 0,2827 \\
$\mathbf{5 2}$ & 0,2158 & 0,2350 \\
\hline
\end{tabular}


Dari data yang diperoleh dapat diketahui bahwa hasil sel paling banyak pada waktu 48 jam baik untuk media tanpa biotin maupun nedia dengan penambahan biotin sehingga kurvanya seperti berikut :

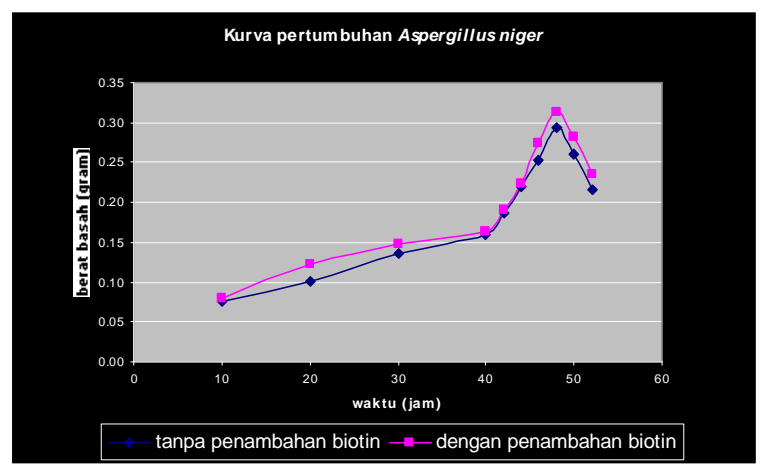

\section{Penentuan biomasa.}

Penentuan biomasa perlu dilakukan untuk mendapatkan informasi seberapa besar peningkatan produksi sel pada media yang tidak ditambahkan biotin dengan media yang ditambah dengan biotin. Dari hasil penelitian menunjukkan bahwa penambahan biotin dapat meningkatkan produksi sel, hal ini sesuai dengan teori bahwa biotin bermanfaat pada pertumbuhan sel .Hasil dari penelitian adalah sebagai beikut :

Tabel 4.2. Berat biomassa Aspergillus niger pada proses produksi asparaginase

\begin{tabular}{|c|c|c|}
\hline Biomassa & $\begin{array}{c}\text { Tanpa } \\
\text { penambahan } \\
\text { biotin }\end{array}$ & $\begin{array}{c}\text { Dengan } \\
\text { penambahan } \\
\text { biotin }\end{array}$ \\
\hline Produksi 1 & 0,0707 gram & $0,0991 \mathrm{gr}$ \\
\hline Produksi 2 & 0,3585 gram & $0,4021 \mathrm{gr}$ \\
\hline
\end{tabular}

Keterangan:

Produksi 1: hasil proses produksi pada volume media $30 \mathrm{~mL}$

Produksi 2: hasil proses produksi pada volume media $90 \mathrm{~mL}$.

\section{KESIMPULAN}

Penambahan biotin $0,1 \mathrm{mg} / \mathrm{mL}$ pada media pertumbuhan Aspergillus niger, yaitu Czapek cair dapat meningkatkan produksi biomassa Aspergillus niger sampai 40,17\%.

\section{UCAPAN TERIMA KASIH :}

Kami mengucapkan banyak terima kasih kepada semua pihak yang telah memberikan sumbangsih baik berupa saran, pendataan, penganalisaan dan periviuan sehingga artikel ini dapat terwujut. Hal ini kami sampaikan terutama kepada Bp.Drs. Damin Sumardjo, Bp.M. Asy'ari MSi., Bp. Drs. Muhammad Hadi, MSi, Sdr Henny S, SSi. Semoga budi baik beliau beliau terbalas oleh-Nya. Amin.

\section{DAFTAR PUSTAKA}

Andarwulan, N., dan Sutrisno, K., 1992, "Kimia Vitamin", Rajawali Press, Jakarta, hal: 160-164.

Bonjour, J. P., 1991, "Biotin. In: Handbook of Vitamins", Marcel Dekker, Inc New York, page: $393-427$.

Fardiaz, S., 1992, "Mikrobiologi Pangan I", PT. Gramedia Pustaka Utama, Jakarta, hal: 180205.

Gandjar, I., Samson, R. A., Santoso, I., dan Oetari, A., 1999, "Pengenalan Kapang Tropik Umum", Yayasan Obor Indonesia, Jakarta, hal: 134.

Holcenberg, J. S., and Robert, J., 1981, "Enzyme as Drugs", John Wiley and Sons, New York, page: $2-15$.

Hadioetomo, dan Ratna S., 1987, "Mikrobiologi Dasar dalam Praktek, Tehnik dan Prosedur Dasar Laboratorium”, PT. Gramedia Pustaka Utama, Jakarta, hal: 73-89.

Poesponegoro, M., dan Oei Ban Liang., 1991, "Pengaruh Limitasi Nutrien pada Fermentasi Asam Sitrat Biak Rendam secara 2 Tahap dengan Aspergillus niger ATCC 11414", di dalam JKTI, vol I, No. 2.

Poedjiadi, A., 1994, "Dasar-dasar Biokimia", UI Press, Jakarta, 158-162.

Samson, R. A., Hoekstra, E. S., and Oorschot, C. A. N., 1996, "Introduction to Food Borne Fungi", Centra Albureau for Schimmcl Cultures, Netherland, page: 4.

Suharto, 1995, "Bioteknologi Dalam Dunia Industri”, Andi Offset, Yogjakarta, hal: 36.

Suhartono, M. T., 1989, "Enzim dan Bioteknologi”, IPB, Bogor, hal: 1-79. 
Wuryanti 